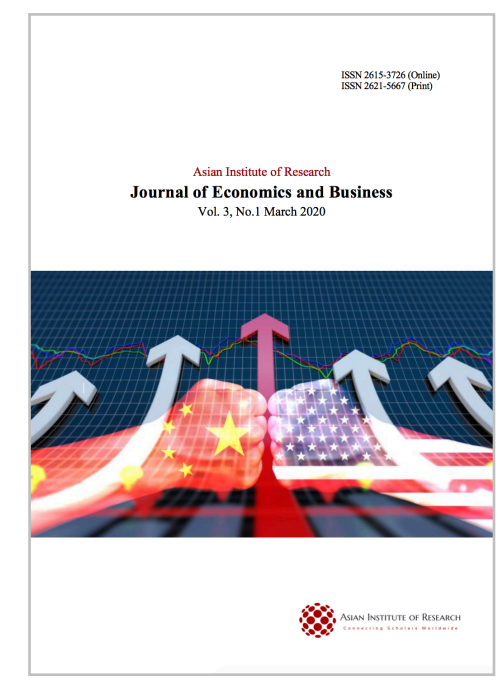

Journal of Economics and Business

Kayode, Peter Akinyemi, Oke, Mikel Ojo, and Adegboyega, Adewoye Olaolu. (2020), Firm Characteristics and Stock Returns of Nigerian Quoted Firms: A TwoSector Comparative Analysis. In: Journal of Economics and Business, Vol.3, No.1, 313-327.

ISSN 2615-3726

DOI: 10.31014/aior.1992.03.01.200

The online version of this article can be found at:

https://www.asianinstituteofresearch.org/

Published by:

The Asian Institute of Research

The Journal of Economics and Business is an Open Access publication. It may be read, copied, and distributed free of charge according to the conditions of the Creative Commons Attribution 4.0 International license.

The Asian Institute of Research Journal of Economics and Business is a peer-reviewed International Journal. The journal covers scholarly articles in the fields of Economics and Business, which includes, but not limited to, Business Economics (Micro and Macro), Finance, Management, Marketing, Business Law, Entrepreneurship, Behavioral and Health Economics, Government Taxation and Regulations, Financial Markets, International Economics, Investment, and Economic Development. As the journal is Open Access, it ensures high visibility and the increase of citations for all research articles published. The Journal of Economics and Business aims to facilitate scholarly work on recent theoretical and practical aspects of Economics and Business. 


\title{
Firm Characteristics and Stock Returns of Nigerian Quoted Firms: A Two-Sector Comparative Analysis
}

\author{
Akinyemi Kayode Peter ${ }^{1}$, Oke Mike Ojo ${ }^{2}$, Olaolu Adegboyega Adewoye ${ }^{3}$ \\ ${ }^{1}$ Lecturer, Department of Banking and Finance, Adekunle Ajasin University, Akungba Akoko, Nigeria. Telp: \\ +2347032236545. Email: akinyemipeter252@gmail.com \\ ${ }^{2}$ Senior Lecturer, Department of Finance, Ekiti State University, Ado-Ekiti, Nigeria \\ ${ }^{3}$ Department of Banking and Finance, Kwara State Polytechnic, Ilorin, Nigeria
}

Correspondence: Kayode Peter Akinyemi. Email: akinyemipeter252@gmail.com

\begin{abstract}
This study examines the relationship between firm characteristics and the stock returns selected banks and manufacturing companies quoted on the Nigerian Stock Exchange on a two-sector basis. The study employs pooled/panel data analytical techniques to analyze the financial data of 15 banks and 15 manufacturing companies quoted on the Nigerian Stock Exchange as of December 31st, 2018. The study finds the effect of firm characteristics on the stock return of financial sector firms is sharply different from that of the manufacturing sector firms. Through the fixed effect model result it was found that in the financial sector, earnings per share and liquidity have a positive and statistically significant relationship with a stock return while return on assets has a negative and statistically significant effect on stock return. Other variables (leverage, market capitalization and sales growth rate) effects on stock return are not statistically significant. On the other hand, in the manufacturing sector, out of the six firm characteristic variables, only market capitalization has a positive and statistically significant effect on stock return. The effects of the other five were not significant. Furthermore, the test of causality shows that in the financial sector, earnings per share, return on assets and liquidity ratio have causal links with stock return. However, in the manufacturing sector, market capitalization and earnings per share have a causal link with stock return. The study recommends that firm managers should develop strategies that will consistently improve stock price, which determines market capitalization and, to some extent, stock returns. Also, financial firms should be wary of overinvestment in assets and/or its underutilization. The need to acquire is desirable. But this can also cause problems when such assets idle away or the cost of maintaining them eats so much into the revenue of the firm. Finally, management should maintain a healthy balance between liquidity and investments; and, policy makers to design and execute policies that are sector sensitive rather than generic in nature.
\end{abstract}

Keywords: Stock Return, Firm Characteristics, Panel Regression, Granger Causality

\section{INTRODUCTION}

Broadly, there are two major objectives of the firm: profit maximization and shareholders' wealth maximization. Other goals such maximization of sales revenue, growth of assets, managerial leisure, managers' satisfaction, market share, power, cost minimization, among others are expected to still aim at the two primary goals (Kotlar, De-Massis, Wright \& Fretini, 2018). 
The profit maximizing goal of the firm is the most popular goal which implies that all managerial decisions and actions should be directed toward the sole end of maximizing profit for the firm. The wealth maximization objective, on the other hand, simply means that business managers direct their activities towards the maximization of the present value of a firm measured in terms of the current market worth of the firm. The current market value of a firm is usually regarded as the price of its stock on the floor of the Stock Exchange market at a given time. To maximize the value of the firm, management is expected to efficiently manage firm characteristics which include activities that form part of the day-to-day and longer-term operations of the firm such as liquidity, profitability, capital structure, market share, investment and earning power. Prombutr and Phengpis (2019) posit that firm characteristic are cogent explainers of stock returns as they are seen as drivers of information and sentiments on stock prices.

Although firm-level characteristics bear the same name among firms, the strategies employed by management in controlling these characteristics differ from one firm to the other. For instance, Prombutr and Phengpis (2019) believe that the behavioural firm level characteristics are the most potent explainers of stock market returns. The extent to which these characteristics are efficiently managed can, to a large extent, dictate the level of stock returns. This is due to the fact that these characteristics dictate the thrust of the firms.

In the modern day dynamic business environment where micro and macroeconomic variables that exert much influence of the operations of the firm keep changing, continuous research is necessary to identify the characteristics that affect organizational performance and value. Ample empirical literature exists on the relationship between firm based characteristics and stock returns of Nigerian quoted firms, but these literatures reveal contradicting results, essentially due to the variables analyzed and the fact that the studies were conducted under different micro- and macro-economic conditions. Some researchers find that firm level characteristics have positive and significant effects on stock return (Uwubanmwen \& Obayagbona, 2012; Okoro \& Stephen, 2014; Idris \& Bala, 2015 ).while others discover negative and significant effects. Yet, other findings reveal a nosignificant relationship situation (Idris \& Bala, 2015). The inconsistencies in these findings call for more research to be carried out on the relationship between these firm level characteristics and the stock returns of selected quoted firms in Nigeria. More importantly, this research is intended to make a comparison of the effects of firm level characteristics on stock returns of firms in the financial sector of the Nigerian economy with that of the manufacturing sector. To the best of this researcher's knowledge, researchers are yet to do much in the attempt to ascertain whether the effects in these two sectors are in anyway different. So far, empirical works have concentrated on establishing the relationship between firm level characteristics and stock returns either on individual firm's basis or on a group of firms' basis. This research seeks to fill this gap created in literature by comparing these effects between the two principal sectors of the economy so as to establish the existence or otherwise of any structural change between them.

The general objective of this study is to examine the effect of firm level characteristics on the stock returns of selected financial and manufacturing firms in Nigeria. However, the specific objectives of the study are to:

i. determine the effects of firm level characteristics on the stock returns of selected quoted financial firms in Nigeria;

ii. determine the effects of firm level characteristics on the stock returns of selected quoted manufacturing firms in Nigeria;

iii. compare the effect of firm level characteristics on the stock returns of selected financial firms with that of selected manufacturing firm in Nigeria; and,

iv. examine the direction of causality between firm level characteristics and stock returns of selected quoted financial and manufacturing firms in Nigeria.

\section{LITERATURE REVIEW}

\subsection{Firm Level Characteristics}

Business organizations have specific plans, policies, decisions, programmes and processes that shape their daily operations. These are firm level characteristics which form the fulcrum of business firms' activities. They are, 
most times, expressed in figures for ease of accounting measurement. Mgeni and Nayak (2016) state that different researchers view firm characteristics in different ways depending on the criteria they use to define it. Notwithstanding, most researchers tend to agree that firm characteristics are related with firm resources and organizational objectives. Kisengo and Kombo (2012) state that firm level characteristics can be broadly categorized into three main groups: structure, capital and market-related. Firm structure related characteristics are firm size, ownership and age; the market related characteristics include industry type, environmental uncertainty and market environment while the capital-related characteristics refer to liquidity and capital intensity.

\subsection{Stock Return}

Stock return is the gain accruable to an investor based on the number of stock such an investor has in the organization. Idris and Bala (2015) define stock return as the returns or gain that the investors generate out of the stock market. Theoretically, stock return is calculated as:

\section{Stock price in the current year-Initial stock price + Current dividend $\mathrm{x} 100$}

Initial stock price

\subsection{Theoretical Literature}

\subsubsection{Determinants of Stock Return}

The theoretical basis for the determinants of stock returns can be tied to the theories of firms value as advanced by Modigliani and Miller (1961), popularly called the dividend irrelevancy theory; the trade-off theory (Myers, 1964); the agency theory; the asymmetric information theory, the pecking order theory (Myers \& Majiluf, 1984) and the traditional approach (Solomon and Weston (1963). Other theories, apart from the Modigliani and Miller (M-M, 1961) proposition are against the dividend irrelevancy school of thought. These other theories relaxe the assumptions upon which the M-M hypotheses were based and hence argue that assumptions such as the existence of perfect capital market, absence of transaction cost and the non-existence of income taxes cannot hold in a real world situation. The Capital Assets Pricing Model (CAPM) proposed by Sharpe (1964), Linter (1965) and Black (1972) were all premised on the assumption that the stock market is efficient and that securities are rightly priced and stock returns can be ascertained by the level of risk the investor assumes. The premise on which the CAPM is built has made it not only defective, but unable to sufficiently predict stock returns. Uwubanmwen and Obayagbona (2012) argue that since the CAPM only captures the systematic risk (firm based), other variables which are out of the control of management (for example, macroeconomic variables such as inflation rate, money market rates, gross domestic product, exchange rates, etc.) also exert great influence in determining or predicting stock returns reliably. This position had earlier been held by Fama and French (1992); Basu (1997) and Drew (2003) among others.

Kogan and Papanikolaou (2012) provide a theoretical model that links firm level characteristics to stock returns using technological shocks as the main component of the model. The researchers observe that firm based characteristics such as Tobin's Q, previous investment spending, earnings-price ratios, market betas, and stock price volatility help predict the share of growth opportunities in the firm's market value,

\subsection{Empirical Literature}

Stakeholders in business organizations are naturally interested in how their interests in such organizations are faring. Managements, shareholders, investors, customers as well as the government should be interested in the performance of business organizations in the economy. For management, organizational performance is a measure of their managerial capabilities; and to investors and shareholders, corporate performance reveal how well their investment is doing. Customers are interested in firms' performance in order to determine whether they will continue doing business with such firms or not while the government is interested in firms' performances, not only for tax purposes, but also for the formulation and implementation of policies that will aid overall economic 
development. Of particular concern to shareholders is the behaviour of return on their stock holding in firms. Shafana, Rinziya and Jariya (2013) state that though shareholders, researchers and policy makers pay more attention to macroeconomic variables, there are other firm level factors that explain stock returns. Such factors include earnings power, dividends payout, risks, leverage, size and liquidity, among others. Prombutr and Phengpis (2019) study the behavioural-related variables within the firms as determinants of stock return in Pakistan and find that more than covariance risks associated with investment, growth and size, behavioural characteristics determine stock returns of firms. Yang, Ryu and Ryu (2017), while studying investors' sentiments and assets return in Korea, analyze a dataset of firms listed on the Korean stock exchange, find that when investor sentiment is high, stock returns are most likely to increase.

Idris and Bala (2015) study the effects of firm characteristics on the stock returns of 9 out of the 21 food and beverage firms quoted on the Nigerian Stock Exchange as at $31^{\text {st }}$ December, 2013. The researchers use panel data regression techniques to examine the relationship between stock market returns and three firm based characteristics namely, market capitalization, earnings per share and debt-to-equity ratio. Their findings show that while debt-toequity ratio and earnings per share have positive and significant relationship with stock returns, market capitalization has negative and significant relationship with stock returns. Okoro and Stephen (2014) examine the determinants of stock price movement in Nigeria for the period 2001-2011 by analyzing the data of 99 firms quoted on the Nigerian Stock Exchange with Ordinary Least Square. Among their findings is that earnings per share affect stock return positively and that the EPS has the strongest explanatory power in explaining stock price movement. In a study conducted by Olowoniyi and Ojenike (2012) to examine the determinants of stock returns of Nigerian listed firms, the researchers use panel data analytical techniques to analyze the financial data of 70 firms and find that expected growth rate and size have positive effects on stock return while tangibility (defined as total fixed assets divided by net profit after tax) inversely affect the stock return of listed firms. Earlier, Okafor (2007) studies the relationship between organizational characteristics and performance of quoted firms in Nigeria by constructing a 4-S (skill, staff, style and shared values) model. The researcher employs the ordinary least square (OLS) technique to analyze the data of a sample of quoted firms in Nigeria and finds that all the independent variables (skill, staff. Style and shared values) have positive relationship with organizational performance. Adedoyin (2011) had earlier arrived at similar conclusion. Shafana, Rimziya and Jariya (2013) investigate the relationship between stock returns and firm size, and book-to-market equity of 12 firms listed on the Colombo (Sri Lanka) Stock Exchange. The authors discover that book-to-market equity affects stock return negatively and significantly and that firm size has no significant effect on stock returns. This finding is also in agreement with that of Chambers, Sezgin and Karaaslan (2013).

\section{RESEARCH METHOD}

\subsection{Theoretical Framework}

This research work is premised on the Capital Assets Pricing Model (CAPM) proposed by Sharpe (1964), Linter (1965) and Black (1972) which gives leanings to the fact that stock prices of firms are determined by systematic (firm based) risks.

\subsection{Model Specification}

This study employed a panel data analysis technique to examine the effect of firm-level characteristics on the stock return of 30 quoted firms in Nigeria. The research work used the panel data econometric technique to test the significance of the effects of selected firm level variables on the firms' stock return. The study adapted a model used by Idris and Bala (2015) in their research on firm's specific characteristics and stock market return (evidence from listed food and beverages firms in Nigeria) with modification. This study modified their model by incorporating firms' level characteristic from capital structure (leverage), earnings power (earnings per share), size (market capitalization), liquidity (current ratio), profitability (return on assets) and sales growth as independent variables for the selected quoted firms in Nigeria. The model for this research is specified as follows:

$$
\mathrm{STR}=\mathrm{f}(\mathrm{LEV}, \mathrm{MCAP}, \mathrm{EPS}, \mathrm{ROA}, \mathrm{CUR}, \mathrm{SGR})
$$


Specifying equation (3.1) in econometric form, it becomes:

$\mathrm{STR}_{\text {it }}=a+\beta 1 \mathrm{LEVit}+\beta_{2} \mathrm{MCAP}_{\text {it }}+\beta_{3} \mathrm{EPS}_{\text {it }}+\beta_{4} \mathrm{ROA}_{\text {it }}+\beta_{5} \mathrm{CUR}_{\mathrm{it}}+\beta_{5} \mathrm{SGR}_{\mathrm{it}}+\varepsilon_{\mathrm{it}}$

Splitting equation 3.2 into the two sectors in our analysis, we have equations (3.3) and (3.4) for financial and manufacturing sectors respectively. That is,

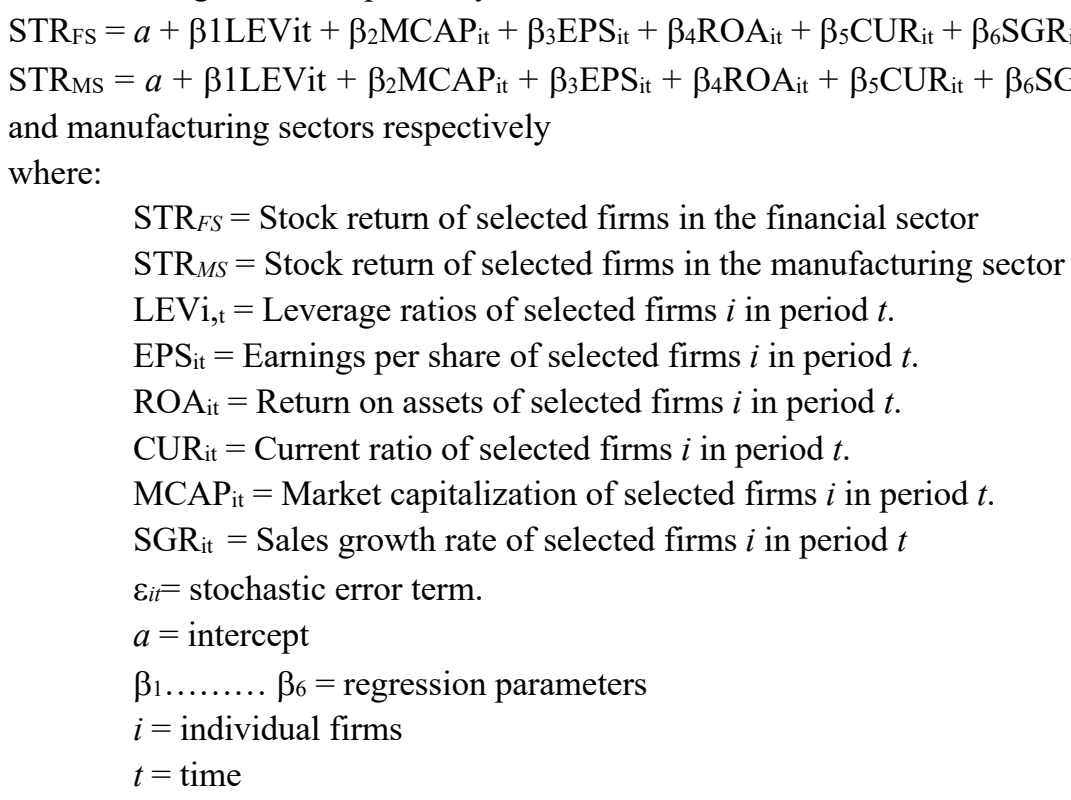

\subsection{Definition of Variables}

Tables 3.1 and 3.2 define the dependent and explanatory variables used in the econometric models stated in equation (3.2).

Table 3.1: Definition of Dependent Variable

\begin{tabular}{|c|l|c|}
\hline S/N & Variable & Definition \\
\hline 1 & Stock Return & $\begin{array}{c}\text { Current price of stock minus initial stock price plus current } \\
\text { dividend, all divided by initial price of stock }\end{array}$ \\
\hline
\end{tabular}

Source: Author's compilation (2020)

Table 3.2: Definition of Independent Variables

\begin{tabular}{|c|l|c|}
\hline S/N & \multicolumn{1}{|c|}{ Variable } & Definition/Formula \\
\hline 1 & Leverage Ratio (LEV) & $\frac{\text { Long }- \text { term debt capital }}{\text { Equity capital }}$ \\
\hline 2 & Market capitalization (MCAP) & Year-end share price x number of ordinary shares \\
\hline 3 & Earnings Per Share (EPS) & $\begin{array}{c}\text { Profit after tax } \\
\text { Number of ordinary shares }\end{array}$ \\
\hline 4 & Return on assets & $\frac{\text { Profit after tax }}{\text { Total assets }}$ \\
\hline 5 & Current Ratio & $\frac{\text { Current assets }}{\text { Current liabilities }}$ \\
\hline 6 & Sales Growth Rate & $\frac{\text { Sales in the current year }- \text { Sales in the previous year } \%}{\text { Sales in the previous year }}$ \\
\hline
\end{tabular}

Source: Author's compilation (2020)

\subsection{Sources of Data}

Data for this study were sourced from secondary sources. The sample size is purposive in nature as it is reliably assumed to be balanced representative of the population. The study used the annual data of 15 selected commercial 
banks and 15 manufacturing firms quoted on the Nigerian Stock Exchange from year 2008 to 2018. The choice of 15 commercial banks and 15 manufacturing companies is due to the fact that all the firms quoted on the stock exchange as at December $31^{\text {st }}, 2018$ are realistically assumed to belong to either the financial (monetary) or manufacturing (real) sector of the economy. Also, the years under study is chosen in order to be able to get sufficient data of the firms under study. The data was sourced from the Nigerian Stock Exchange daily price list, and the annual financial reports of the selected firms.

\subsection{Estimation Techniques}

\subsubsection{Panel Data Analysis}

A panel data is in the form of $n$ subjects, each with $T$ observations measured at $1 \ldots . . t$ period so that the total number of observations in the panel is $n T$. The data set for this study comprises of the stock returns, leverage ratio, return on assets, liquidity (current) ratio, earnings per share, sales growth and market capitalization of the selected firms. The data cover a period of ten (10) years from 2008-2018. The dependent variable is the stock return (STR) while the other variables are explanatory variables. In addition, fixed and random effect tests are carried out on the regression results to determine the preferred model.

The fixed effects model is denoted as

$$
\begin{aligned}
& y_{i t},=\alpha+\beta^{\prime} X_{i t}+\mu_{i t}, \\
& \mu_{i t}=\mu_{i}+v_{i t} .
\end{aligned}
$$

$\mu_{i}$ are individual-specific, time-invariant effects because they are taken as fixed over time

The random effects model stated as:

$$
\mu_{i} \approx \text { i.i.d.N }\left(0, \sigma_{\mu}^{2}\right)
$$

and,

$$
v_{i t} \approx i . i . d . N\left(0, \sigma_{v}^{2}\right)
$$

assumes that the two error components are independent from each other.

The Hausman test is used to select the most appropriate model out of the two. This test is employed to determine the existence of any significant difference between the estimates of the fixed effect regression and that of the random effect regression. It follows the asymptotic chi-square distribution with the null hypothesis that the random effect is most appropriate.

\subsubsection{Test of Causality among Variables}

In this study, Granger (1969) test of causality between dependent and explanatory variables is used to ascertain if there exists causality between stock return and firm characteristic variables and the direction of causality. Granger (1960) states the causality test in the form of:

$$
\begin{aligned}
& Y_{t}=\sum_{i=1}^{k} a_{i} X_{t-i}+\sum_{j=1}^{k} b_{j} Y_{t-j}+u_{1, t} \\
& X_{t}=\sum_{i=1}^{k} c_{i} Y_{t-i}+\sum_{j=1}^{k} d_{j} X_{t-j}+u_{2, t}
\end{aligned}
$$

where $X$ and $Y$ in the equations are stationary time series.

Generally, the Granger causality test ascertains if previous changes in one stationary variable $X_{t}$ can assist in predicting current behaviours in another stationary variable $Y_{t}$, more than the explanation provided by past changes in $Y_{t}$ itself (Granger, 1969). If not, then $X_{t}$ does not "Granger cause" $Y_{t .}$. 
The decision rule from Equations (3.8) and 3.9), is that the null hypothesis that $X$ does not Granger cause $Y$ is rejected if $a_{t}$ and $d_{t}$ are jointly significant.

\subsection{Evaluation Techniques}

The evaluation techniques used in this study to test for significance, reliability and theoretical consistency include the economic a-priori expectation, the statistical criteria (coefficient of multiple determination $\left(R^{2}\right)$ and the test of overall significance $(F$-test).

\subsection{A-priori Expectation}

This study theoretically expects that earnings per share, dividend per share, total assets, sales growth and market capitalization have positive and significant relationship with stock return; while leverage ratio has negative and significant relationship with stock return.

\subsection{ANALYSIS, FINDINGS AND DISCUSSION}

\subsection{Pooled Regression Results}

This research made use of Pooled regression (Ordinary Least Square, OLS) technique in analyzing the data of 30 selected quoted firms in Nigeria. The pooled OLS regression result assumes that the coefficients and constant estimates are fixed for all cross sectional observations. That is, the OLS is based on the assumption of absence of heterogeneity in cross sectional and time series data.

Objective 1: Determination of the effects of firm level characteristics on the stock returns of selected quoted financial firms in Nigeria

Table 4.1 is the summary of pooled regression results of model 3.3 that show the relationship between firm characteristics and stock return of financial sector under study.

Table 4.1: Abridged Pooled OLS Regression Result for financial sector firms

\begin{tabular}{|c|r|r|r|r|}
\hline Dependent Variable $=$ STR \\
\hline Variable & Coefficient & Std. Error & t-Statistic & Prob. \\
\hline LEV & $5.12 \mathrm{E}-05$ & 0.000283 & 0.180503 & 0.8571 \\
\hline MCAP & -0.001915 & 0.000769 & -2.490963 & 0.0142 \\
\hline EPS & 0.201674 & 0.027624 & 7.300665 & 0.0000 \\
\hline ROA & -0.024845 & 0.009873 & -2.516382 & 0.0133 \\
\hline CUR & 0.843579 & 0.192062 & 4.392216 & 0.0000 \\
\hline SGR & 0.119044 & 0.117956 & 1.009218 & 0.3151 \\
\hline C & -0.651579 & 0.201435 & -3.234681 & 0.0016 \\
\hline R-Squared & & 0.474192 & \\
\hline Adjusted R-Squared & & 0.445770 & 16.68392 \\
\hline F-Statistic & & 0.000000 & \\
\hline Prob (F-Statistic) & & & \\
\hline
\end{tabular}

Source: Authors' computation (2020)

The first objective of this study is to find out the effects of firm based characteristics on the stock returns of the selected financial firms that are quoted on the Nigeria Stock Exchange (NSE). This objective is captured in the null hypothesis that firm based characteristics have no significant effect on stock returns of financial firms that are quoted on the NSE. The results in Table 4.1 show that two out of the six firm based characteristics (LEV and SGR) have positive but statistically insignificant effect on stock return. A unit increase in LEV and SGR will lead to a statistically insignificant effects of 0.0000512 and 0.119044 on STR as confirmed by probabilities of 0.8571 and 
0.3151 for LEV and SGR respectively. EPS and CUR are positively and statistically significant effect on stock return. A unit rise in EPS and CUR will bring about a statistically significant increase of 0.201674 and 0.843579 increase in STR respectively as revealed by their probabilities of 0.0000 and 0.0000 respectively. The other two (MCAP and ROA) have negative and statistically significant effect on stock return. A unit increase in MCAP and ROA means that STR will fall to the tune of -0.001915 and -0.024845 respectively. This fall is statistically significant with probabilities of 0.0142 and 0.0133 for MCAP and ROA respectively.

The coefficient of determination $\left(R^{2}\right)$ of 0.474192 implies that about $47 \%$ of the variations in stock returns are explained by the firm based characteristics studied while the remaining $53 \%$ is explained by other variables outside the scope of the research model. The F-Statistic (16.68392) and F-probability $(0.0000)$ indicate that the research model is statistically significant in its overall assessment.

However, the OLS technique assumes that regression coefficients and constants are homogeneous for all crosssectional observations. This assumption ignores the probability of individuality or heterogeneity among the 30 selected firms. This possibility of this assumption not holding necessitates the need to subject our results to fixed and random effect tests so as to know the most appropriate model that should be used in arriving at conclusion.

\subsubsection{Fixed and Random Effect Tests}

The basis for a fixed effect model is that it assumes heterogeneity or individuality of observations such that each selected firm has its distinct intercept value. In essence, the fixed-effect model assumes that though the intercept may differ across individual firms, it is fixed over time. The purpose of the fixed effect test is to reveal the effect of other variables that are outside of the pooled OLS model used in the study.

On the other hand, the random effect model assumes that all the subjects in the sample size (firms) possess a uniform mean value as intercept. The interpretation of this is that the heterogeneity is random and is included in the overall error term. The summary of both the fixed and the random effect tests results are shown in Table 4.2.

Table 4.2: Fixed and random effects models regression results for financial sector firms

\begin{tabular}{|c|c|c|c|c|c|c|c|c|c|}
\hline \multicolumn{5}{|c|}{ Fixed Effects Model } & \multicolumn{5}{|c|}{ Random Effects Model } \\
\hline \multicolumn{5}{|c|}{ Dependent Variable $=$ STR } & \multicolumn{5}{|c|}{ Dependent Variable $=$ STR } \\
\hline Variable & Coefficient & Std. Error & $\mathrm{t}$-Statistic & Prob. & Variable & Coefficient & Std. Error & t-Statistic & Prob. \\
\hline LEV & 0.000184 & 0.000223 & 0.822754 & 0.4127 & LEV & 0.000136 & 0.000218 & 0.623282 & 0.5344 \\
\hline MCAP & -0.000218 & 0.001111 & -0.196658 & 0.8445 & MCAP & -0.000815 & 0.000876 & -0.93002 & 0.3544 \\
\hline EPS & 0.109350 & 0.024799 & 4.409430 & 0.0000 & EPS & 0.131288 & 0.023577 & 5.568432 & 0.0000 \\
\hline ROA & -0.020842 & 0.007632 & -2.731079 & 0.0075 & ROA & -0.021968 & 0.007486 & -2.93469 & 0.0041 \\
\hline CUR & 0.473097 & 0.178002 & 2.657818 & 0.0092 & CUR & 0.594561 & 0.166763 & 3.565316 & 0.0005 \\
\hline SGR & 0.067752 & 0.083770 & 0.808790 & 0.4206 & SGR & 0.076511 & 0.083432 & 0.917054 & 0.3611 \\
\hline $\mathrm{C}$ & -0.216993 & 0.191918 & -1.130658 & 0.2610 & $\mathrm{C}$ & -0.341292 & 0.189334 & -1.80259 & 0.0742 \\
\hline \multicolumn{3}{|c|}{$R$-Squared } & \multicolumn{2}{|l|}{0.778456} & \multicolumn{3}{|c|}{ R-Squared } & \multicolumn{2}{|l|}{0.270565} \\
\hline \multicolumn{3}{|c|}{ Adjusted R-Squared } & \multicolumn{2}{|l|}{0.732777} & \multicolumn{3}{|c|}{ Adjusted R-Squared } & \multicolumn{2}{|l|}{0.231136} \\
\hline \multicolumn{3}{|c|}{ F-Statistic } & \multicolumn{2}{|l|}{17.04183} & \multicolumn{3}{|l|}{ F-Statistic } & \multicolumn{2}{|l|}{6.862084} \\
\hline \multicolumn{3}{|c|}{$\operatorname{Prob}(F$-statistic) } & \multicolumn{2}{|l|}{0.000000} & \multicolumn{3}{|c|}{ Prob(F-statistic) } & \multicolumn{2}{|l|}{0.000003} \\
\hline
\end{tabular}

Source: Author's computation (2020).

Table 4.2 contains the summary of the results of both the fixed and the random effect models for financial sector firms. The decision to use any of the above models and results will be determined by the Hausman test. 


\subsubsection{The Hausman Test for financial sector firms}

The problem of errors in model specification that may arise in panel data analysis is the focus of Hausman (1978) test. This test assists in determining the right choice of model to use in ascertaining the existence (or otherwise) of substantial difference(s) between the estimates of the fixed and random effect estimators. The Hausman test statistic is expressed as an asymptotic chi-square distribution based on one hypothesis expressed in null and alternative forms as follows:

$\mathrm{H}_{0}: \quad$ Random effect model is more appropriate

$\mathrm{H}_{1}$ : $\quad$ Fixed effect model is more appropriate

In order to determine which of the hypotheses to accept or reject, the probability of calculated Chi-statistic is compared with the $5 \%$ significance level. If Chi-statistic is higher than the $5 \%$ level of significance, then the null hypothesis cannot be rejected. The reverse will be the case if it is lesser. Table 4.3 contains the extract from the result of Hausman test.

Table 4.3: Extracts from Hausman test cross-section random effects test for financial sector firn

\begin{tabular}{lccc}
\hline \hline Test Summary & Chi-Sq. Statistic & Chi-Sq. d.f. & Prob. \\
\hline \hline Cross-section random & 13.489183 & 6 & 0.0359 \\
\hline \hline
\end{tabular}

Source: Author's Computation with E-Views 8 (2020).

From Table 4.3, the value of Chi-Statistic is 13.489183 and its probability is 0.0359 , which is less than the $5 \%$ significance level. This implies that the null hypothesis cannot be accepted and the alternative hypothesis cannot be rejected, hence, the fixed effect model is more appropriate for the purpose of analyzing the first objective of this study.

From Table 4.2, the fixed effect model estimates show that out of the six explanatory variables in model 3.3, two (EPS and CUR) have positive and statistically significant effects on STR. This is reflected in coefficients of 0.109350 and 0.47397 and probabilities of 0.0000 and 0.0092 respectively. A unit increase in EPS and CUR will lead to increases of 0.109350 and 0.4739 in STR respectively. In contrast, ROA has a negative and statistically significant effect on STR with coefficient of -0.020842 and probability value of 0.0075 . An increase in ROA will lead to a reduction of -0.020842 . LEV and SGR both have positive but statistically insignificant effects on STR with coefficients 0.000184 and 0.067752 and probabilities of 0.412 and 0.4206 respectively. On its part, MPCA has negative but statistically insignificant effect on STR with coefficient -0.000218 and a probability of 0.8445 . While four of the explanatory variables, namely EPS, CUR, LEV and SGR agree with the a-priori expectation two, ROA and MCAP run contrary to it.

The coefficient of determination, $R,{ }^{2}$ a measure of the percentage of variable STR explained by the LEV, EPS, MCAP, ROA, CUR and SGR is 0.778456 implying that about $78 \%$ of the variations in STR is explained LEV EPS, MCAP, ROA, CUR and SGR. The remaining $22 \%$ is explained by other variables outside the model. The $F$ Statistics of 17.04183 and its probability of 0.00000 imply that model 3.3 is statistically reliable to explain the effect of firm characteristics on stock returns of selected financial sector firms in Nigeria.

\section{Objective 2: Determination of the effects of firm level characteristics on the stock returns of selected quoted manufacturing firms in Nigeria}

The next focus of this study is to determine the relationship between firm characteristics and stock returns of selected manufacturing sector firms quoted on the Nigerian Stock Exchange.

Table 4.4 contains the abridged results of pooled regression for the manufacturing sector model. 
Table 4.4: Abridged pooled regression result for manufacturing sector firms

\begin{tabular}{|c|r|r|r|r|}
\hline Dependent Variable $=$ STR \\
\hline Variable & Coefficient & Std. Error & t-Statistic & Prob. \\
\hline LEV & -0.002812 & 0.005886 & -0.477843 & 0.6336 \\
\hline MCAP & 0.011065 & 0.005316 & 2.081502 & 0.0396 \\
\hline EPS & 0.111523 & 0.027588 & 4.042434 & 0.0001 \\
\hline ROA & 0.202987 & 0.059344 & 3.420500 & 0.0009 \\
\hline CUR & -2.900833 & 0.724689 & -4.002864 & 0.0001 \\
\hline SGR & 0.021459 & 0.087084 & 0.246419 & 0.8058 \\
\hline C & 5.213758 & 1.158379 & 4.500910 & 0.0000 \\
\hline R-Squared & & 0.385812 & 0.354582 \\
\hline Adjusted R-Squared & & 12.35394 & \\
\hline F-Statistic & & 0.000000 & \\
\hline Prob (F-Statistic) & &
\end{tabular}

Source: Authors' Computation (2020)

Results from Table 4.4 show that three of the six explanatory variables, namely, MCAP, EPS and ROA have positive and statistically significant effect on STR with coefficients $0.011065,0.111523$ and 0.202987 and probabilities of 0.0396, 0.0001 and 0.0009 respectively. A unit increases in MCAP, EPS and ROA will bring about increases of $0.011605,0.11523$ and 0.202987 in STR respectively. The CUR has a negative and statistically significant effect on STR with coefficient -0.2900833 and probability of 0.0001 . A unit increase in CUR will bring about a decline of 0.2900833 in STR. A unit increase in LEV will also bring about a decline of 0.002812 in STR but the relationship is not statistically significant $(p=0.6336)$. Lastly, a unit rise in SGR will lead an increase of about 0.021549 in STR though the effect is statistically insignificant $((p=0.8058)$.

The coefficient of determination, $R,^{2}$ a measure of the percentage of variable STR explained by the LEV, EPS, MCAP, ROA, CUR and SGR is 0.385812 implying that only about $39 \%$ of the variations in STR is explained LEV EPS, MCAP, ROA, CUR and SGR. The remaining $61 \%$ is explained by other variables outside the model. The $F$-Statistics of 12.35394 and its probability of 0.00000 imply that model 3.4 is statistically reliable to explain the effect of firm characteristics on stock returns of selected manufacturing sector firms in Nigeria. The results of the fixed and random effects tests are shown in Table 4.5

Table 4.5: Fixed and random effects model regression results for manufacturing sector firms

\begin{tabular}{|c|c|c|c|c|c|c|c|c|c|}
\hline \multicolumn{5}{|c|}{ Fixed Effects Model } & \multicolumn{5}{|c|}{ Random Effects Model } \\
\hline \multicolumn{5}{|c|}{ Dependent Variable $=$ STR } & \multicolumn{5}{|c|}{ Dependent Variable $=$ STR } \\
\hline Variable & Coefficient & Std. Error & t-Statistic & Prob. & Variable & Coefficient & Std. Error & t-Statistic & Prob. \\
\hline LEV & -0.005218 & 0.003334 & -1.56511 & 0.1206 & LEV & -0.004709 & 0.003272 & -1.43887 & 0.1528 \\
\hline MCAP & 0.011404 & 0.006024 & 1.893030 & 0.0411 & MCAP & 0.011233 & 0.005148 & 2.181893 & 0.0311 \\
\hline EPS & 0.028652 & 0.016537 & 1.732591 & 0.0861 & EPS & 0.040224 & 0.015939 & 2.523576 & 0.0129 \\
\hline ROA & 0.030068 & 0.039551 & 0.760227 & 0.4488 & ROA & 0.067045 & 0.037968 & 1.765841 & 0.0800 \\
\hline CUR & -0.004854 & 0.545048 & -0.00891 & 0.9929 & CUR & -0.694004 & 0.512338 & -1.35458 & 0.1781 \\
\hline SGR & 0.075762 & 0.046525 & 1.628429 & 0.1065 & SGR & 0.061713 & 0.046061 & 1.339812 & 0.1829 \\
\hline $\mathrm{C}$ & 2.583067 & 0.834042 & 3.097047 & 0.0025 & $\mathrm{C}$ & 3.492892 & 0.995230 & 3.509634 & 0.0006 \\
\hline \multicolumn{3}{|c|}{$R$-Squared } & \multicolumn{2}{|l|}{0.865855} & \multicolumn{3}{|c|}{$R$-Squared } & \multicolumn{2}{|l|}{0.171399} \\
\hline \multicolumn{3}{|c|}{ Adjusted R-Squared } & \multicolumn{2}{|l|}{0.840058} & \multicolumn{3}{|c|}{ Adjusted R-Squared } & \multicolumn{2}{|l|}{0.129266} \\
\hline \multicolumn{3}{|c|}{ F-Statistic } & \multicolumn{2}{|l|}{33.56412} & \multicolumn{3}{|c|}{ F-Statistic } & \multicolumn{2}{|l|}{4.068104} \\
\hline \multicolumn{3}{|c|}{$\operatorname{Prob}(F$-statistic $)$} & \multicolumn{2}{|l|}{0.000000} & \multicolumn{3}{|c|}{$\operatorname{Prob}(F$-statistic $)$} & \multicolumn{2}{|l|}{0.000961} \\
\hline
\end{tabular}

Source: Author's computation (2020).

Table 4.5 contains the summary of the results of both the fixed and the random effect models for manufacturing sector firms. The decision to use any of the above models and results will be determined by the Hausman test. 


\subsubsection{The Hausman Test for manufacturing sector firms}

Table 4.6

\begin{tabular}{lccc}
\hline \hline Test Summary & $\begin{array}{c}\text { Chi-Sq. } \\
\text { Statistic }\end{array}$ & Chi-Sq. d.f. & Prob. \\
\hline \hline Cross-section random & 46.712747 & 6 & 0.0000 \\
\hline \hline
\end{tabular}

Source: Author's Computation with E-Views 8 (2020).

Form Table 4.6 the value of Chi-Statistic is 46.712747 and its probability is 0.0000 , which is less than the $5 \%$ significance level. This implies that the null hypothesis cannot be accepted and the alternative hypothesis cannot be rejected, hence, the fixed effect model is more appropriate for the purpose of analyzing the first objective of this study.

The estimates of the fixed effect model show that MCAP, EPS, ROA and SGR all have positive effects on STR with coefficients $0.01104,0.028652,0.030068$ and 0.046525 respectively). However, only one of these effects (MCAP with $\mathrm{p}$ value $=0.0411$ ) is statistically significant. The effect of the others EPS, ROA and SGR is not statistically significant due to their probability values $(0.0611,0.0861,0.4488$ and 0.1065 respectively). On the other hand, LEV and CUR have negative effects on STR with coefficients -0.005218 and -0.004854 respectively). Again these effects are not statistically significant as revealed by their probability values (0.1206 for LEV and 0.9929 for CUR). While MCAP, EPS, ROA and SGR agree with the a-priori expectation, LEV and CUR contradict it.

Notwithstanding, the $R,{ }^{2}$ of 0.865855 shows that about $87 \%$ of the behaviour of STR is explained by the explanatory variables while the remaining $13 \%$ is explained by other variables outside model 3.4 . The $F$-Statistics is 33.56412 with a probability of 0.0000 showing that model 3.4 is statistically reliable to explain the relationship between the characteristics of manufacturing sector firms in Nigeria and their stock returns.

These results affirm the position of the Capital Assets Pricing Model (CAPM) that stock price, and by implication, stock return is determined by firms based (systematic) risks

\section{Objective 3: Comparative Analysis}

The third focus of this research is to compare the effects of firm level characteristics on the stock returns of financial with those of manufacturing firms in Nigeria. This comparison is made in Table 4.7.

Table 4.7: Comparative between financial and manufacturing sector firms' results

\begin{tabular}{|c|c|c|c|c|c|c|}
\hline \multicolumn{7}{|c|}{$\begin{array}{l}\text { Dependent Variable: STR } \\
\text { Method: Panel Least Squares }\end{array}$} \\
\hline & \multicolumn{3}{|c|}{ Financial sector firms (Fixed Effect) } & \multicolumn{3}{|c|}{ Manufacturing sector firms (Fixed Effect) } \\
\hline Variable & Coefficient & Prob. & Remark & Coefficient & Prob. & Remarks \\
\hline LEV & 0.000184 & 0.4127 & $\begin{array}{l}\text { Positive, } \\
\text { insignificant }\end{array}$ & -0.005218 & 0.1206 & $\begin{array}{l}\text { Negative, } \\
\text { insignificant }\end{array}$ \\
\hline MCAP & -0.000218 & 0.8445 & $\begin{array}{l}\text { Negative, } \\
\text { insignificant }\end{array}$ & 0.011404 & 0.0411 & Positive, significant \\
\hline EPS & 0.109350 & 0.0000 & Positive, significant & 0.028652 & 0.0861 & Positive, insignificant \\
\hline $\mathrm{ROA}$ & -0.020842 & 0.0075 & Negative, significant & 0.030068 & 0.4488 & Positive, insignificant \\
\hline CUR & 0.473097 & 0.0092 & Positive, significant & -0.004854 & 0.9929 & Positive, insignificant \\
\hline SGR & 0.067752 & 0.4206 & $\begin{array}{l}\text { Positive, } \\
\text { insignificant }\end{array}$ & 0.075762 & 0.1065 & Positive, insignificant \\
\hline & $R^{2}$ & 0.778456 & High & $R^{2}$ & 0.865855 & High \\
\hline
\end{tabular}




\begin{tabular}{|l|l|l|l|l|l|l|}
\hline & F-Statistic & 17.04183 & & F-Statistic & 33.56412 & \\
\hline & Prob(F-stat $)$ & 0.000000 & Absolutely reliable & Prob(F-stat $)$ & 0.000000 & Absolutely reliable \\
\hline
\end{tabular}

Source: Author's computation on E-Views 8 (2020)

Table 4.7 reveals a marked difference in the effects of firm based variables on stock return between financial and manufacturing firms in Nigeria. While three (3) firm level variables (EPS, ROA and CUR) have significant effects on STR of the financial sector firms, only MCAP has significant effect on STR of the manufacturing sector firms. Also, from the Table, out of the six firm level variables studied, only sales growth rate (SGR) has the same effect (positive, insignificant) on STR.

\section{Objective 4: Causality tests}

Table 4.8 Comparison of causality results of financial and manufacturing sector firms

\begin{tabular}{|c|c|c|c|c|c|}
\hline \multicolumn{3}{|c|}{$\begin{array}{c}\text { Financial sector firms } \\
\text { Dependent Variable }=\text { STR }\end{array}$} & \multicolumn{3}{|c|}{$\begin{array}{l}\text { Manufacturing sector firm } \\
\text { Dependent Variable }=\text { STR }\end{array}$} \\
\hline Variable & Prob. & Conclusion & Variable & Prob. & Conclusion \\
\hline $\begin{array}{l}\text { LEV cause STR } \\
\text { STR cause LEV }\end{array}$ & $\begin{array}{l}0.9988 \\
0.7132\end{array}$ & $\begin{array}{l}\text { No causal } \\
\text { relationship }\end{array}$ & $\begin{array}{l}\text { LEV cause STR } \\
\text { STR cause LEV }\end{array}$ & $\begin{array}{l}0.2627 \\
0.9044\end{array}$ & $\begin{array}{l}\text { No causal } \\
\text { relationship }\end{array}$ \\
\hline $\begin{array}{l}\text { MCAP cause STR } \\
\text { STR cause MCAP }\end{array}$ & 0.2590 & $\begin{array}{l}\text { No causal } \\
\text { relationship }\end{array}$ & $\begin{array}{l}\text { MCAP cause STR } \\
\text { STR cause MCAP }\end{array}$ & 0.0337 & $\begin{array}{l}\text { Uni-directional } \\
\text { causality from } \\
\text { MCAP to STR }\end{array}$ \\
\hline $\begin{array}{l}\text { EPS cause STR } \\
\text { STR cause EPS }\end{array}$ & $\begin{array}{r}0.0021 \\
4 \mathrm{E}-05 \\
\end{array}$ & $\begin{array}{l}\text { Bi-directional } \\
\text { causality between } \\
\text { EPS and STR }\end{array}$ & $\begin{array}{l}\text { EPS cause STR } \\
\text { STR cause EPS }\end{array}$ & $\begin{array}{l}0.0542 \\
0.0095\end{array}$ & $\begin{array}{l}\text { Uni-directional } \\
\text { causality that runs } \\
\text { from EPS to STR }\end{array}$ \\
\hline $\begin{array}{l}\text { ROA cause STR } \\
\text { STR cause ROA }\end{array}$ & $\begin{array}{l}0.0167 \\
0.0886\end{array}$ & $\begin{array}{l}\text { Unidirectional } \\
\text { causality from } \\
\text { ROA to STR }\end{array}$ & $\begin{array}{l}\text { ROA cause STR } \\
\text { STR cause ROA }\end{array}$ & $\begin{array}{l}0.4965 \\
0.3917\end{array}$ & $\begin{array}{l}\text { No causal } \\
\text { relationship }\end{array}$ \\
\hline $\begin{array}{l}\text { CUR cause STR } \\
\text { STR cause CUR }\end{array}$ & $\begin{array}{l}0.7266 \\
0.0003\end{array}$ & $\begin{array}{l}\text { Unidirectional } \\
\text { causality from } \\
\text { STR to CUR }\end{array}$ & $\begin{array}{l}\text { CUR cause STR } \\
\text { STR cause CUR }\end{array}$ & $\begin{array}{l}0.5760 \\
0.0821\end{array}$ & $\begin{array}{l}\text { No causal } \\
\text { relationship }\end{array}$ \\
\hline $\begin{array}{l}\text { SGR cause STR } \\
\text { STR cause SGR }\end{array}$ & $\begin{array}{l}0.5975 \\
0.5514\end{array}$ & $\begin{array}{l}\text { No causal } \\
\text { relationship }\end{array}$ & $\begin{array}{l}\text { SGR cause STR } \\
\text { STR cause SGR }\end{array}$ & $\begin{array}{l}0.5659 \\
0.4529\end{array}$ & $\begin{array}{l}\text { No causal } \\
\text { relationship }\end{array}$ \\
\hline
\end{tabular}

Source: Author's computation with EViews 8(2020)

From the results of the causality tests in Table 4.8, it is shown that only the three (3) firm level characteristics that have significant relationship with stock returns of financial sector firms also have causal link with it that is bidirectional, unidirectional and unidirectional causality between EPS, ROA and CUR with STR respectively. On the other hand, among the manufacturing sector firms, two of the firm level variables (MCAP and EPS) have unidirectional causality that runs from them to STR.

\subsection{Summary and Conclusions}

This study was undertaken to achieve three main objectives. First, the study examined the effect of firm based characteristics on stock returns of quoted financial and manufacturing sector firms in Nigeria. Second, the study did a comparative analysis of the effect of firm based characteristics on stock returns of the financial sector firms with that of manufacturing sector firms quoted on the Nigeria Stock Exchange. Finally, the study examined and 
compared the existence and direction (or otherwise) of causality between firm based characteristics on stock returns of the firms on a two sector basis.

Results of the fixed effect model obtained from the panel least squares (PLS) regression show that in the financial sector, leverage and sales growth rate positively affect stock returns but the effect is not statistically significant. Furthermore, market capitalization negatively affects stock return but this effect is also not statistically significant. Earnings per share and liquidity ratio exert positive and statistically significant effect on stock return. Return on assets, on its part, has a statistically significant negative effect on stock return of the selected firms. Earnings per share and liquidity ratio obviously agree with the a-priori expectation out of the six firm characteristics examined. The negative and statistically significant effect of return on assets on stock return deserves a special attention as it should naturally affect stock return positively. This negative and significant effect can be attributable to overinvestment in assets or assets underutilization. In this case, the return on assets will be sub-optimal, showing absence of good assets management by Nigerian financial institutions. The positive and significant effect of earnings per share and liquidity ratio on stock return is expected as effective management of working capital as well as increased earnings per share will encourage investors to buy more of the firms stock which may bring about a rise in stock price. A rise in stock prices will also translate into higher stock returns.

In the manufacturing sector, however, only market capitalization has a positive and statistically significant effect on stock return and this is expected. For all the other firm characteristics considered, their effects on stock returns are not statistically significant. In essence, these results contradict the a-priori expectation of the relationship between firm characteristics and stock returns.

Moreover, comparing the results of causality test of financial sector firms with those of manufacturing sector firms shows that only the firm characteristics that have significant effect on stock return of financial sector firms also have causal relationship with it. That is earnings per share (bi-directional); return on assets (uni-directional to stock return) and liquidity ratio (uni-directional from stock return). In the manufacturing sector, market capitalization has uni-directional causality to stock return) while earnings per share also have uni-directional relationship that runs from stock returns.

This study reveals that the effects of firm based characteristics on stock return can be sector-sensitive. Firm characteristics affect stock return more in the financial sector than in the manufacturing sector. This brings to the fore the need for firm managers and policymakers to develop and implement strategies and policies that are particularly suitable for different sectors of the economy.

\subsection{Recommendation}

Based on the findings of this study, the researcher recommends as follows:

1. Apart from macro-economic variables that affect stock prices and returns, firm based characteristics also, to a large extent, affect it especially among financial sector firms in Nigeria. Firm managers should develop strategies that will consistently improve stock return, which determines market capitalization and, to some extent, stock returns. The fact that some firm based characteristics have positive but insignificant effects on stock returns suggests that such firm based characteristics can do better and significantly affect stock returns, hence, the need for management to optimally manage such characteristics.

2. Not all firm based characteristics significantly propel high stock returns. To maximize shareholders' return (especially those who prefer current dividends to a future promise of it), management should focus more on variables that have a causal relationship with stock returns.

3. Financial firms should be wary of overinvestment in assets and its underutilization. The need to acquire is desirable. But this can also cause problems when such assets idle away or the cost of maintaining them eats so much into the revenue of the firm. 


\subsection{Contribution to Knowledge}

Management, as well as investors, are particularly interested in knowing how their investments are doing. To the investor, stock return is one major indicator of the performance of his investment. Stock return is very sensitive to occurrences at the firm level of each organization, essentially because it depends much on earnings and dividends. The relationship between activities within the firm environment and what stockholders eventually get as return on their investment is a topical issue that has attracted much attention in finance. Empirical literature on the relationship between firm based characteristics and stock return have dwelt on the mixed results obtained and the generalization of findings. In addition to confirming the inconsistencies reported in literature, this study contributes significantly to the body of knowledge by comparing the effects on sector basis. The study discovers that the effect of firm based characteristics on stock return of the firms in the financial sector is different from that of the manufacturing sector of the Nigerian economy. Finally, this research contributes to the body of knowledge on the subject of the causality between firm level characteristics and stock returns of quoted firms in Nigeria on sector basis and the direction of such causality.

\section{References}

Adedoyin, A. O. (2011). Share price determinants and corporate characteristics. MSc Dissertation, Department of Accounting, College of Development Studies, Covenant University, Otta, Nigeria.

Ahmad, H.., Fida, B. A. \& Zakaria, M. (2013). The co-determinants of capital structure and stock returns: Evidence from the Karachi stock exchange. Lahore Journal of Economics, 18 (1), 81-92

Basu, S. (1997). The conservatism principle and the asymmetric timeliness of earnings. Journal of Accounting \& Economics, 24 (1), 3-37

Black. F. (1972), Capital market equilibrium with restricted borrowing. Journal of Business, 45, 444-455.

Black, F. Jensen, M. \& Scholes, M. (1972). The capital asset pricing model: some empirical tests, in Studies in the Theory of Capital Markets, Praeger, New York, 79- 121

Chambers, N., Sezgin, F. H. \& Karaaslan, B. (2013). An analysis of the effect of capital structure and the beta coefficient on stock returns: a case study of the Istanbul stock exchange's manufacturing industry. International Journal of Business and Social Science, 4 (7), 45-60

Drew, M. E. (2003). Beta, firm size, book-to-market equity and stock returns. Journal of the Asia Pacific Economy, 8 (3), 354-379

Fama, E. F. \& French, K. (1992). The cross-section of expected stock returns. Journal of Finance, 47, 427-465.

Hamed, G \& Prahalad, G. K (1994). Competing for the future. Harvard Business School, Boston

Idris, I. \& Bala, H. (2015). Firms' specific characteristics and stock market returns (Evidence from listed food and beverages firms in Nigeria). Research Journal of Finance and Accounting, 6(16), 188-200

Kisengo, Z. M, Kombo, H. (2012) Effect of firm characteristics on performance of the microfinance sector in Nakuru Kenya. International Journal of Science Research. 3(7), 122-132

Kogan, L. \& Papanikolaou, D, (2012). A theory of firm characteristics and stock returns: The role of investmentspecific shocks, NBER Working Paper No. 17975

Kotlar, J., De-Massis, A., Wright, M. \& Fretini, F. (2018). Organizational goals: Antecedents, formation processes and implications for firm behaviour and performance, International Journal of Management Reviews, 20(1), Retrieved from: DOI: 10.1111/ijmr.12170

Lintner, J. (1965). The valuation of risk assets and the selection of risky investment in stock portfolios and capital budgets. Review of Economic Statistics, 47, 13-37.

Mgeni, T. O, \& Nayak, P. (2016.) Impact of structural firm characteristics on business performance of SMEs: Evidence from agribusiness firms in Dar Es salaam, Tanzania. Arabian Journal of Business Management Review, 6, 246.

Myers, S. C. \& Majluf, N. S., (1984). Corporate Financing and Investment Decisions when firms have information that investors do not have. Journal of Financial Economics, 13(2), 187-221.

Okafor, C. (2007). Organizational characteristics and performance in Nigerian quoted companies. Research Journal of Business Management 1(1), 37-49

Okoro, E. G. \& Stephen, E. A. (2014). Determinants of stock price movement in Nigeria (Evidence from the Nigerian stock exchange). Journal of Economics and Sustainable Development, 5 (3), 101-118

Olowoniyi A. O \& Ojenike J.O. (2012). Determinants of stock return of Nigerian-listed firms. Journal of Emerging Trends in Economics and Management Sciences, 3(4), 389-392

Prombutr, W. \& Phengpis, C. (2019). Behavioural-related firm characteristics and risks and determinants of stock returns, Reviews of Accounting and Finance, 18(1), 95-112 
Shafana, M. A., Rimziya, A. L \& Jariya, A. M. (2013). Relationship between stock returns and firm size, and book-to- market equity: empirical evidence from selected companies listed on Milanka Price Index in Colombo Stock Exchange, Journal of Emerging Trends in Economics and Management Sciences 4(2):217-225

Sharpe, W. F. (1964). Capital asset prices: A theory of market equilibrium under conditions of risk. Journal of Finance, 18, 424-447.

Solomon, E. \& Weston, F. (1963). The Theory of Financial Management, New York: Colombia University Press

Tahir, S. H., Sabir, H. M., Alam, T. \& Ismail, A. (2013). Impact of firms' characteristics on stock returns: a case of non-financial listed firms in Pakistan. Asian Economics and Financial Review, 3 (1), 51-61

Uwubanmwen, A. E. \& Obayagbona, J. (2012). Company fundamentals and returns in the Nigerian stock exchange. JORIND, $10(2), 52-66$.

Yang H., Ryu, D. \& Ryu, D. (2017). Investor sentiment, asset returns and firm characteristics: Evidence from the Korean stock market, Investment Analysts Journal 46(2), 132-147 